\title{
Aleksandra Łukasik
}

\section{ZASADA KONTRADYKTORYJNOŚCI W MAEŻEŃSKIM PROCESIE SKRÓCONYM PRZED BISKUPEM ${ }^{*}$}

Wprowadzenie do prawa kanonicznego nowej instytucji procesowej, jaką jest małżeński proces skrócony przed biskupem, uzasadnić można chęcią przyspieszenia i uproszczenia postępowania dotyczącego stwierdzania nieważności małżeństwa. Należy jednak podkreślić, iż dojście do prawdy o zaskarżanym małżeństwie możliwe jest tylko przy zachowywaniu od samego początku regulujących takie postępowanie sądowe norm prawnych oraz zasad procesowych. Jest to niezwykle istotną kwestią, szczególnie, że na przebieg procesu składa się wiele czynności dokonywanych przez wszystkie podmioty biorące w nim udział.

\section{ZASADA KONTRADYKTORYJNOŚCI. ZAŁOŻENIA GENERALNE}

Zasada kontradyktoryjności jest jedną z podstawowych zasad procesowych. Będąc ściśle związaną ze strukturą iudicium, jest zasadą odnoszącą

MGR LIC. AlEKSANDRA ŁUKASIK, DOKTORANT - Katedra Kościelnego Prawa Procesowego, Małżeńskiego i Karnego oraz Katolickich Kościołów Wschodnich, Instytut Prawa Kanonicznego, Wydział Prawa, Prawa Kanonicznego i Administracji, Katolicki Uniwersytet Lubelski Jana Pawła II; e-mail: aleksandra.rybaczek@wp.pl; https://orcid.org/ 0000-0002-2880-1307

* Niniejszy artykuł powstał w wyniku realizacji projektu badawczego nr UMO2017/25/N/HS5/02554, finansowanego ze środków Narodowego Centrum Nauki. 
się do stron procesu. Warto przy tym zauważyć, że zasada kontradyktoryjności nie została wprost zapisana w normach prawa kanonicznego regulujących postępowanie sądowe. Niemniej ma ona zasadniczy wpływ na przebieg postępowania od rozpoczęcia procesu aż do jego definitywnego rozstrzygnięcia [Greszata 2008, 263].

Każdy, zarówno ochrzczony, jak i nieochrzczony, może występować przed sądem (kan. 1476) ${ }^{1}$. Prawo to zaś złączone jest z ukonstytuowaniem się kontradyktoryjnej relacji procesowej [del Amo 2011, 1112]. Tym samym strony biorące udział $\mathrm{w}$ postępowaniu wobec sędziego, realizują zasadę kontradyktoryjności będąc podmiotami toczącego się sporu. W procesie o stwierdzenie nieważności małżeństwa praktycznym wymiarem zasady kontradyktoryjności jest działanie stron w stosunku do przedmiotu sporu, a więc w odniesieniu do powstałej wątpliwości co do faktu ważnego zawarcia małżeństwa [Greszata 2008, 242]. W odniesieniu do zasady kontradyktoryjności należy stwierdzić, iż wobec sędziego zawsze muszą istnieć dwa podmioty, które w stosunku do siebie wysuwają sprzeczne twierdzenia. W sprawach o orzeczenie nieważności małżeństwa mogą w tym kontekście zaistnieć dwie sytuacje. Strony wobec siebie mogą zgłaszać przeciwstawne tezy (jedna strona uważać będzie małżeństwo za nieważnie zawarte, podczas gdy drugi małżonek będzie przekonany o jego ważności) lub też oboje małżonkowie mogą poddawać w wątpliwość ważność swojego małżeństwa, a wszelkie argumenty przeciwko jego nieważności będzie w takiej sytuacji przedstawiał występujący w procesie obrońca węzła małżeńskiego (kan. $1432 \mathrm{KPK} / 83$ ). Gwarancją realizacji zasady kontradyktoryjności w procesie jest prowadzenie racjonalnego dialogu [Arroba Conde 2016, 93-99]. Kontradyktoryjność można przy tym określić mianem „sporu w płaszczyźnie intelektualnej, w sytuacji gdy istnieją przynajmniej dwie, różne od siebie racjonalne możliwości rozumienia danej kwestii” [Greszata 2008, 256]. Zasada kontradyktoryjności zakłada więc istnienie dwóch przeciwstawnych tez. Nie można bowiem mówić o kontradykcji, jak brak jest tezy przeciwnej do jakiegoś twierdzenia, w sytuacji, gdy dwie tezy nie znoszą się wzajemnie, czy wówczas kiedy tezy dotyczą różnych kwestii i nie sprzeciwiają się sobie [tamże, 253].

${ }^{1}$ Codex Iuris Canonici auctoritate Ioannis Pauli PP. II promulgatus (25.01.1983), AAS 75 (1983), pars II, s. 1-317; tekst polski: Kodeks Prawa Kanonicznego, przekład polski zatwierdzony przez Konferencję Episkopatu, Pallottinum, Poznań 1984 [dalej cyt.: KPK/83]. 
Zasada kontradyktoryjności nieodłącznie związana jest z zasadą równości stron oraz zasadą dwustronności. W chwili powstania stanu zawisłości spornej jest zasadą konsekwentnie odnoszącą się do obu stron prowadzących spór, traktując je w sposób sprawiedliwy. Równość stron jest niejako skutkiem kontradykcji, wyrażając się przede wszystkim w równości uprawnień przysługujących stronom $\mathrm{w}$ stosunku do wszystkich czynności procesowych [Taż 2003, 248, 256]. Należy ponadto podkreślić, że kontradyktoryjność jest nie tylko warunkiem, ale i niezbędną gwarancją dojścia do prawdy w procesie [Dotti 2005, 242]. Zapewnia niejako ochronę osobom biorącym udział w postępowaniu i umożliwia im działanie, także podejmowane jako obrona wobec innych uczestników procesu [Zuanazzi 1994, 33644]. Co więcej, stanowi podstawę dla tworzenia określonych regulacji normujących prawa i obowiązki przysługujące poszczególnym uczestnikom procesu [Greszata 2008, 242]. Zasada kontradyktoryjności związana jest także z powinnościami stron w kontekście instrukcji sprawy. Jej konsekwencją jest bowiem ciążący na stronach obowiązek gromadzenia i przedstawiania środków dowodowych na potwierdzenie swojej tezy (kan. 1526 $\S 1 \mathrm{KPK} / 83$ ) [del Amo 2011, 1148-149]. Istotę zasady kontradyktoryjności stanowi zaś swego rodzaju „walka stron”. Przytaczając argumenty świadczące o słuszności prezentowanego stanowiska strony muszą popierać je dowodami (kan. $1527 \S 1 \mathrm{KPK} / 83$ ). Sędzia z kolei ma za zadanie ocenić tak zebrany materiał dowodowy i wydać na jego podstawie wyrok rozstrzygający spór. Musi ponadto sprawować kontrolę nad spierającymi się stronami, aby ich „walka” nie wykraczała poza ściśle przyjęte reguły i wyrażała się w możliwościach podjęcia działania określonych dla każdej strony przez normy prawne [Greszata 2008, 259-60]. Kontradyktoryjność wydaje się więc być tym elementem w procesie, który narzuca stronom aktywność [Bonnet 2018, 81]. Jednocześnie jednak powinno się ją interpretować w kategoriach współpracy stron podejmowanej w celu uzyskania rozstrzygnięcia kwestii spornej między nimi [Ariano 2017, 182].

\section{MAŁŻEŃSKI PROCES SKRÓCONY PRZED BISKUPEM}

Papież Franciszek w 2015 r. przeprowadził reformę spraw o orzeczenie nieważności małżeństwa. Wydany przez niego list apostolski motu proprio 
Mitis Iudex Dominus Iesus ${ }^{2}$ wprowadza nową instytucję prawa procesowego - małżeński proces skrócony przed biskupem. Przebieg procesu o stwierdzenie nieważności małżeństwa prowadzonego w trybie procesu skróconego można podzielić na kilka etapów. Początkową fazą procesu jest wprowadzenie sprawy, a do kolejnych można zaliczyć instrukcję sprawy skoncentrowaną na sesji dowodowej oraz dyskusję sprawy z uwagami przedwyrokowymi obrońcy węzła małżeńskiego i głosami obrończymi stron, a także decydujący etap postępowania, jakim jest wyrokowanie, w ramach którego odbywa się przekazanie akt sprawy biskupowi diecezjalnemu, konsultacja biskupa $\mathrm{z}$ instruktorem i asesorem, osiągnięcie moralnej pewności przez biskupa diecezjalnego oraz wydanie wyroku lub przekazanie sprawy do rozpatrzenia w trybie procesu zwykłego. Ostatnim etapem procesu, który jednak nie zawsze będzie występował, jest zaskarżenie wyroku.

Małżeński proces skrócony przed biskupem jest formą procesu nadzwyczajnego [Greszata-Telusiewicz 2015, 79], a prowadzony może być wyłącznie po spełnieniu określonych w prawie warunków. Zgodnie bowiem z normami wprowadzonymi przez wspomniane motu proprio, aby rozpocząć proces o nieważność małżeństwa w trybie procesu skróconego żądanie musi zostać zgłoszone przez obydwoje małżonków lub przez jednego z nich za zgodą drugiego oraz przytoczone mają zostać okoliczności dotyczące faktów lub osób, poparte zeznaniami lub dokumentami, które nie wymagają przeprowadzenia dokładniejszego badania albo dochodzenia, a w sposób oczywisty wskazują na nieważność zaskarżanego małżeństwa (kan. 1683 MIDI). Konieczne jest, aby warunki były spełnione łącznie. Pierwszy z nich może zostać zrealizowany bądź poprzez złożenie wspólnie podpisanej skargi powodowej, bądź przez wyraźne i pozbawione wątpliwości wyrażenie zgody przez jednego małżonka na prowadzenie procesu skróconego, o który wnosi drugi małżonek [Góralski 2017, 61-68; Gałkowski 2016, 39-41]. Z kolei jako przykłady wskazujące na spełnienie drugiego warunku w postaci okoliczności wskazujących w sposób oczywisty na nieważność małżeństwa

\footnotetext{
${ }^{2}$ Franciscus PP., Litterae apostolicae motu proprio Mitis Iudex Dominus Iesus quibus canones Codicis Iuris Canonici de Causis ad Matrimonii nullitatem declarandam reformatur (15.08.2015), AAS 107 (2015), s. 958-67; tekst polski w: Franciszek, List apostolski motu proprio Mitis Iudex Dominus Iesus reformujacy kanony Kodeksu Prawa Kanonicznego dotyczqce spraw o orzeczenie nieważności matżeństwa (tekst łacińsko-polski), Wydawnictwo Diecezji Tarnowskiej Biblos, Tarnów 2015 [dalej cyt.: MIDI].
} 
można wymienić: taki brak wiary, który może prowadzić do symulacji konsensu lub błędu determinującego wolę, krótki czas pożycia małżeńskiego, aborcja dokonana dla uniknięcia zrodzenia potomstwa, uporczywe pozostawanie $\mathrm{w}$ relacji pozamałżeńskiej $\mathrm{w}$ czasie zawierania małżeństwa lub wkrótce po ślubie, podstępne zatajenie bezpłodności, poważnej choroby zakaźnej, potomstwa z wcześniejszego związku lub pozbawienia wolności, zawarcie małżeństwa $\mathrm{z}$ przyczyny całkowicie obcej życiu małżeńskiemu lub wynikającej z nieoczekiwanej ciąży kobiety, użycie przemocy fizycznej w celu wymuszenia konsensu oraz brak używania rozumu potwierdzony dokumentacją medyczną (art. 14 Zasad proceduralnych) ${ }^{3}$ [Adamowicz 2015, 100-107; Nowicka 2015, 43-60; Wenz 2016, 320-63]. Należy jednak podkreślić, że przytoczone wyżej okoliczności nie stanowią nowych tytułów nieważności małżeństwa ${ }^{4}$.

Każdy proces rozpoczyna się od wprowadzenia sprawy. W przypadku małżeńskiego procesu skróconego przed biskupem ten etap swoim zakresem obejmuje złożenie skargi powodowej razem z prośbą o rozpatrzenie sprawy w trybie procesu skróconego, decyzję wikariusza sądowego odnośnie do złożonej skargi oraz mianowanie instruktora i asesora. Już na wstępie należy podkreślić, iż skarga powodowa, będąca niezbędnym i inicjującym elementem procesu (kan. $1502 \mathrm{KPK} / 83$ ), musi być złożona zarówno przez uprawnione do tego osoby, jak i być skierowana do kompetentnego trybunału. Zatem to małżonkowie poddający w wątpliwość ważność zawartego przez nich małżeństwa powinni skierować swoją prośbę o przeprowadzenie procesu do trybunału miejsca, w którym małżeństwo zostało zawarte lub trybunału miejsca, w którym jedna ze stron lub obie strony mają stałe lub tymczasowe zamieszkanie lub też trybunału miejsca, w którym faktycznie trzeba będzie zebrać większość dowodów (kan. 1672 MIDI). Konkretnie zaś skarga o nieważność małżeństwa razem z prośbą o rozpatrzenie sprawy w trybie procesu skróconego powinna być złożona do biskupa diecezjalnego i/lub wikariusza sądowego ${ }^{5}$. Co ważne, skarga powodowa

\footnotetext{
${ }^{3}$ Zasady proceduralne w sprawach o stwierdzenie nieważności małżeństwa stanowiące integralną część MIDI [dalej cyt.: Zasady proceduralne].

${ }^{4}$ Tribunale Apostolico Della Rota Romana, Sussidio applicativo del Motu pr. Mitis Iudex Dominus Iesus, Città del Vaticano, gennaio 2016; tekst polski w: Trybunał Apostolski Roty Rzymskiej, Subsydium aplikacyjne do Motu pr. Mitis Iudex Dominus Iesus (brak daty dziennej dokumentu; na karcie tytułowej znajduje się informacja: „Watykan, styczeń 2016”) [dalej cyt.: Subsydium aplikacyjne], s. 33.

${ }^{5}$ Subsydium aplikacyjne, s. 37.
} 
mająca rozpocząć proces skrócony, oprócz spełniania podstawowych wymogów formalnych (kan. $1504 \mathrm{KPK} / 83$ ), powinna przedstawiać krótko, całościowo i jasno fakty, na których opiera się żądanie, a także wskazać dowody, które mogłyby być natychmiast zebrane przez sędziego oraz zawierać w załączeniu dokumenty, na których opiera się żądanie (kan. 1684 MIDI). Warto zauważyć, że wymogi te służą nie tylko przyspieszeniu postępowania, ale przede wszystkim uwiarygodnieniu okoliczności w sposób oczywisty wskazujących na nieważność zaskarżanego małżeństwa, a tym samym możliwości zastosowania w danej sprawie trybu skróconego [Majer 2015, 172].

Po wpłynięciu skargi powodowej do sądu musi zostać podjęta decyzja bądź o przyjęciu skargi do przewodu sądowego, bądź o jej odrzuceniu. Rozstrzygnięcie tej kwestii należy do wikariusza sądowego, który powinien jak najszybciej wydać dekret w tej sprawie (1676 § 1 MIDI). Przed podjęciem czynności musi mieć on jednak pewność, że małżeństwo rozpadło się definitywnie (kan. 1675 MIDI). W sytuacji, kiedy przedstawiona skarga powodowa spełnia wszystkie niezbędne warunki, wikariusz sądowy, przyjmując ją zarządza doręczenie kopii skargi obrońcy węzła małżeńskiego oraz wyznacza piętnastodniowy termin na wyrażenie przez strony stanowiska odnośnie do przedmiotu żądania procesowego (kan. $1676 \S 1$ MIDI). Po upływie wskazanego czasu wikariusz sądowy, wysłuchawszy wcześniej zdania obrońcy węzła małżeńskiego, powinien dekretem określić formułę wątpliwości oraz określić rodzaj procesu w danej sprawie (kan. $1676 \S 2$ MIDI). Jeżeli postępowanie ma toczyć się $\mathrm{w}$ trybie procesu skróconego, wówczas wikariusz sądowy w tym samym dekrecie, w którym określa formułę wątpliwości, po powołaniu instruktora i asesora wzywa na posiedzenie dowodowe wszystkich, którzy powinni wziąć w nim udział (kan. 1685 MIDI).

W małżeńskim procesie skróconym przed biskupem obligatoryjny jest udział zarówno instruktora, jak i asesora [Majer 2015, 177]. Są to osoby wspomagające biskupa diecezjalnego w prowadzeniu procesu. Do funkcji instruktora wikariusz sądowy może powołać zarówno siebie, jak i inną kompetentną osobę (art. 16 Zasad proceduralnych). Zadania instruktora mogą podjąć się zarówno duchowni, jak i wierni świeccy, którzy odznaczają się dobrymi obyczajami, roztropnością i wiedzą ${ }^{6}$ I chociaż instruktor nie musi spełniać wymogów dotyczących posiadania stopnia doktora lub

\footnotetext{
${ }^{6}$ Tamże, s. 39.
} 
przynajmniej licencjata prawa kanonicznego, gdyż nie jest on sędzią sensu stricto [Góralski 2017, 109-10], to istotna rola, jaką pełni w procesie skróconym wymusza posiadanie przez niego odpowiedniego przygotowania prawnego [Bianchi 2016, 70], jak i odznaczania się wystarczającą zdolnością intelektualną i biegłością, która jest niezbędna, aby w sposób skuteczny przeprowadzić instrukcję dowodową [Krukowski 2007, 45]. Warto przy tym zauważyć, że zadanie instruktora w procesie skróconym nie jest związane z orzekaniem w sprawie [Góralski 2017, 109]. Obok instruktora, osobą wspierającą biskupa diecezjalnego w prowadzeniu procesu skróconego jest także asesor. Jego rolę mogą pełnić zarówno duchowni, jak i wierni świeccy, odznaczający się dobrymi obyczajami oraz mający aprobatę biskupa do podjęcia tej funkcji [Pawlak 2007, 358-62]. Osobę asesora można określić jako doradcę pozbawionego władzy jurysdykcyjnej, którego funkcja ma charakter wyłącznie pomocniczy i konsultacyjny [Pikus 2009, 81; Sztychmiler 2000, 690]. Brak jest bowiem dokładnie wyznaczonego zakresu czynności wykonywanych przez asesora. Można jednak stwierdzić, że asesor bierze czynny udział $\mathrm{w}$ procesie poprzez studiowanie akt procesowych. Jego głównym zadaniem jest zaś opiniowanie sprawy w jej toku oraz bezpośrednio przed wydaniem wyroku [Pawluk 1990, 191; Román Sánchez 2018, 266-69]. W procesie skróconym opinia asesora, tak jak i instruktora, wyrażana jest przede wszystkim podczas konsultacji z biskupem diecezjalnym. Będąc skonkretyzowaną możliwością rozstrzygnięcia, popartą argumentami, może przybliżyć sędziego-biskupa do osiągnięcia pewności moralnej w rozpatrywanej sprawie [Pawlak 2007, 365].

Kolejnym etapem postępowania, do którego należy przejść po ukonstytuowaniu się stron procesowych, wyznaczeniu składu trybunału oraz określeniu formuły wątpliwości procesowej, jest instrukcja sprawy. Stanowi ona centralną część postępowania sądowego dostarczającą dowodów będących podstawą orzeczenia [Góralski 2017, 130-31; del Pozzo 2016, 169-70]. W kontekście procesu skróconego niezwykle ważna jest jednoznaczność materiału dowodowego warunkująca prowadzenie procesu $\mathrm{w}$ tym trybie. Z drugiej jednak strony należy podkreślić, iż nieważności małżeństwa nie można z góry zakładać, ale należy ją udowodnić (kan. 1060 KPK/83). W celu przeprowadzenia instrukcji sprawy wikariusz sądowy wyznacza posiedzenie dowodowe. Zawiadomienie o jego miejscu i terminie skierowane jest do stron, obrońcy węzła małżeńskiego i świadków [Wenz 2016, 315]. Osobą odpowiedzialną za cały przebieg postępowania dowodowego 
jest instruktor. Prowadząc i kierując dochodzeniem czuwa on nad porządkiem sesji [del Pozzo 2016, 175; Rozkrut 2018c, 184]. Podejmuje także decyzje co do przeprowadzenia konkretnych dowodów, które co do zasady powinny zostać zebrane podczas jednego posiedzenia (kan. 1686 MIDI). Pomimo skróconej procedury procesu nie jest jednak wykluczona możliwość, w razie szczególnej konieczności, przeprowadzenia więcej niż jednego posiedzenia dowodowego ${ }^{7}$. W sprawach o stwierdzenie nieważności małżeństwa prowadzonych w trybie procesu skróconego środkami dowodowymi przedkładanymi podczas instrukcji sprawy są przede wszystkim oświadczenia stron, zeznania świadków oraz dokumenty. Aby jednak mogły one zostać dopuszczone w procesie powinny być celowe, godziwe, trafne i użyteczne [del Amo 2011, 1148-150; Witkowski 2014, 87-107]. Powinny ponadto uwidaczniać okoliczności w sposób oczywisty wskazujące na nieważność małżeństwa (kan. 1683, n. 2 MIDI). Co jest istotne, w trakcie sesji dowodowej strony mogą być obecne podczas składania oświadczeń przez siebie nawzajem oraz podczas przesłuchań świadków (art. 18 § 1 Zasad proceduralnych). Jest to rozwiązanie sprzyjające szybkości postępowania. Strony bowiem od razu zapoznają się z całością materiału dowodowego zgromadzonego $\mathrm{w}$ sprawie oraz mogą na bieżąco reagować na ujawniane fakty. Z drugiej jednak strony obecność stron podczas składania zeznań przez świadków może wpływać na swobodę wypowiedzi. W tym kontekście, przed instruktorem stoi zadanie odpowiedniego poprowadzenia sesji dowodowej, nie wykluczając $w$ takich sytuacjach wyłączenia obecności stron [Góralski 2017, 128]. Niezależnie od obecności poszczególnych osób na sesji dowodowej, wszystkie odpowiedzi stron i świadków powinny być zredagowane na piśmie przez notariusza, jednakże tylko sumarycznie i w tym co należy do istoty małżeństwa będącego przedmiotem sporu (art. $18 \S 2$ Zasad proceduralnych).

Po przeprowadzeniu instrukcji dowodowej, następuje etap dyskusji sprawy. Bezpośrednio po zebraniu dowodów, gdyż w procesie skróconym nie ma miejsca publikacja akt [Majer 2015, 183; Góralski 2017, 141], instruktor wyznacza termin piętnastu dni na przedstawienie uwag na korzyść węzła małżeńskiego oraz wniosków obrończych stron (kan. 1686 MIDI). Należy przy tym wskazać, iż uwagi przedwyrokowe obrońcy węzła

\footnotetext{
${ }^{7}$ Tamże, s. 39.
} 
małżeńskiego są obligatoryjne, podczas gdy strony nie mają obowiązku przedstawiania swoich pism obrończych [Majer 2015, 183-84].

Orzekanie w sprawach o nieważność małżeństwa prowadzonych w trybie procesu skróconego należy wyłącznie do biskupa diecezjalnego. Ta forma procesu przypisana została bowiem do jego urzędu pasterskiego [del Pozzo 2016, 64-65]. I chociaż osobisty udział biskupa w procesie skróconym rozpoczyna się dopiero na etapie wyrokowania, to jest to aktywność decydująca. W tym kontekście można zauważyć, że zadania biskupa diecezjalnego skupiają się wokół kilku zagadnień. Najważniejszym z nich jest oczywiście wydanie wyroku, jednakże zanim dojdzie do tego etapu, biskup musi przyjąć akta sprawy od instruktora i je przeanalizować, a także skonsultować się z instruktorem i asesorem, po czym, po uzyskaniu moralnej pewności powziąć decyzję rozstrzygającą sprawę.

Po zakończeniu etapu dyskusji sprawy cały materiał zgromadzony podczas procesu w aktach sprawy należy przekazać biskupowi diecezjalnemu (kan. 1687 \& 1 MIDI). Po czynnościach techniczno-formalnych, a więc sprawdzeniu zawartości akt i sporządzeniu adnotacji o ich przyjęciu, biskup powinien przejść do przeanalizowania dostarczonych dokumentów. Chociaż charakter procedury może skłaniać do bardzo szybkiej analizy akt sprawy, to jednak obowiązkiem biskupa diecezjalnego jest wnikliwe zapoznanie się $\mathrm{z}$ całością przekazanego mu materiału. Jedynie bowiem rzetelne przestudiowanie zgromadzonej w procesie dokumentacji pozwoli na ukształtowanie poglądu na sprawę. Podjęcie decyzji wymaga zweryfikowanej z rzeczywistością znajomości faktów oraz świadomości odnośnie do całej sytuacji [tamże, 199]. Szczególną zaś uwagę biskup diecezjalny powinien zwrócić nie tylko na zasadność prośby skierowanej w skardze powodowej, ale również na uwagi obrońcy węzła małżeńskiego oraz pisma obrończe stron. Po zapoznaniu się $\mathrm{z}$ aktami sprawy biskup diecezjalny ma skonsultować się z instruktorem oraz asesorem (kan. 1687 § 1 MIDI), z którymi to będzie mógł omówić własny pogląd na rozpatrywaną sprawę oraz wszelkie nasuwające mu się wątpliwości. Należy jednak podkreślić, iż konsultacja biskupa $\mathrm{z}$ instruktorem i asesorem nie tworzy kolegium podejmującego decyzję dotyczącą ważności małżeństwa. Instruktor i asesor nie są upoważnieni do współdecydowania [Góralski 2017, 151-52], gdyż to wyłącznie biskup może orzekać w procesie skróconym [Wenz 2016, 366]. Tym samym, jeżeli biskup diecezjalny osiągnął moralną pewność co do nieważności małżeństwa [Dzierżon 2015, 114-24], wydaje wyrok stwierdzający, że 
małżeństwo zostało zawarte nieważnie. W przeciwnym razie, wydając odpowiedni dekret, przekazuje sprawę do rozpatrzenia w trybie procesu zwykłego (kan. 1687 \& 1 MIDI). Przepisy dotyczące procesu skróconego nie wskazują, w jakim czasie biskup diecezjalny powinien dokonać wymaganych od niego czynności. Z uwagi jednak na przyspieszony tryb postępowania podjęcie przez biskupa decyzji o rozstrzygnięciu danej sprawy nie może się przedłużać [Rozkrut 2018b, 61-62]. Pełny tekst wyroku wraz $\mathrm{z}$ uzasadnieniem przedstawiającym motywy podjętej decyzji $\mathrm{w}$ sposób zwięzły i uporządkowany (art. $20 \S 2$ Zasad proceduralnych) powinien zostać notyfikowany stronom w ciągu miesiąca (kan. $1687 \S 2$ MIDI). Wyrok w procesie skróconym staje się wykonalny po upływie piętnastu dni użytecznych od wiadomości o publikacji wyroku, jeżeli nie została złożona apelacja lub po upływie terminów na złożenie apelacji, czy też w momencie kiedy trybunał drugiej instancji odrzucił zgłoszoną apelację (kan. 1679 MIDI). Należy wskazać, że prawo do zaskarżenia wyroku przysługuje stronom w każdej sytuacji, w której nie zgadzają się z wydanym orzeczeniem (kan. 1687 § 3 MIDI). W kontekście procesu skróconego jednak strony, otrzymując wyrok stwierdzający ich małżeństwo za nieważnie zawarte uzyskują rozstrzygnięcie zgodne ze złożoną prośbą [Arroba Conde i Izzi 2017, 159; Greszata-Telusiewicz 2015, 89-91]. Nie jest jednak wykluczona możliwość złożenia apelacji przez obrońcę węzła małżeńskiego, broniącego w sposób rozumny ważności zawartego związku małżeńskiego [tamże, 89; Rozkrut 2018a, 271-90; Montini 2017, 301-39].

\section{APLIKACJA ZASADY KONTRADYKTORYJNOŚCI W PROCESIE SKRÓCONYM}

Należy podkreślić, że przez sam fakt zawarcia małżeństwo staje się przedmiotem dobra publicznego. Sposób orzekania o ważności wyrażonej zgody małżeńskiej, także w nowym, skróconym trybie procesu, musi być więc realizowany na drodze postępowania sądowego [Wenz 2016, 192; Daniel 2015, 540-45], gwarantującego w najwyższym stopniu ochronę prawdy świętego węzła małżeńskiego (MIDI, Preambuła, 11). Małżeński proces skrócony przed biskupem stanowiąc jedną $\mathrm{z}$ form procesu o stwierdzenie nieważności małżeństwa za swoją podstawę ma przepisy zwykłego procesu spornego (kan. 1691 MIDI). W konsekwencji również w procesie 
skróconym zasada kontradyktoryjności znajduje swoje zastosowanie jako jedna z podstawowych zasad prawa procesowego.

W sytuacji, kiedy powstanie wątpliwość co do ważności zawartego przez małżonków związku sakramentalnego, mają oni prawo zwrócenia się do trybunału kościelnego z prośbą o wyjaśnienie tej kwestii. Wraz ze złożeniem skargi powodowej małżonkowie, w kontekście procesu skróconego czyniąc to w sposób zgodny, przekazują sędziemu kościelnemu prawo do rozstrzygnięcia o ewentualnej nieważności zaskarżonego małżeństwa. Skutkiem powyższych czynności jest formalne powstanie kontradykcji [Greszata 2008, 253]. Wyraźny charakter kontradyktoryjny procesu ujawnia się zaś najbardziej z chwilą dokonania cytacji [del Pozzo 2016, 149; Napolitano 2015, 559].

W małżeńskim procesie skróconym przed biskupem wspólna prośba małżonków eliminuje między nimi niezgodność, ale nie likwiduje kontradyktoryjności. Zasada kontradyktoryjności wyraża się bowiem w przeciwności pozycji procesowych, a nie w sporze między konkretnymi osobami [del Pozzo 2016, 102-104]. Jak już było wspomniane, kontradyktoryjność opiera się na istnieniu dwóch przeciwstawnych tez. W stosunku do pierwszej można użyć sformułowania dictio (mówienie), podczas gdy treść drugiej tezy to contra dictio (mówienie przeciwnie) [Greszata 2008, 250]. W procesie o stwierdzenie nieważności małżeństwa oba wykluczające się twierdzenia odnoszą się do faktu zawarcia małżeństwa. Z jednej strony, zgodnie z domniemaniem ważności małżeństwa, Kościół stoi na stanowis$\mathrm{ku}$, że małżeństwo należy uważać za ważnie zawarte, dopóki nie udowodni się czegoś przeciwnego (kan. $1060 \mathrm{KPK} / 83$ ). Odmienne stanowisko zajmują natomiast małżonkowie uważający swoje małżeństwo za nieważnie zawarte. W konsekwencji, podczas procesu argumenty na poparcie swoich tez przytaczać będą strony procesowe oraz obrońca węzła małżeńskiego, który występuje w imieniu Kościoła [Taż 2005, 256].

$\mathrm{Na}$ etapie przyjmowania skargi powodowej sędzia powinien mieć świadomość sprzeczności stanowisk odnoszących się do przedmiotu sporu. Zasada kontradyktoryjności zapewnia mu jednak pewną obiektywność, gdyż do aktywnego działania w procesie zobowiązuje przede wszystkim strony zaskarżające małżeństwo [Taż 2008, 253-54]. Niemniej należy zaznaczyć, szczególnie w kwestii procesu skróconego, że niejako gwarantem istnienia kontradyktoryjności jest obrońca węzła małżeńskiego. W każdym procesie 
o stwierdzenie nieważności małżeństwa jest konieczny jego czynny i świadomy udział [Morán Bustos 2016, 138-39; Moreno 2017, 184-91].

W trakcie postępowania, zarówno stronom procesowym, jak i obrońcy węzła przysługują określone uprawnienia (1434 KPK/83). Służą im one bądź do wykazania nieważności małżeństwa, bądź do wskazania, że nie zostały przytoczone argumenty w wystarczającym stopniu świadczące o takiej nieważności. W odniesieniu do zasady kontradyktoryjności istotne znaczenie ma ustalenie formuły wątpliwości procesowej. Chociaż pierwsza propozycja określenia przedmiotu sporu wychodzi od stron składających skargę powodową (kan. $1513 \mathrm{KPK} / 83$ ), to obrońca węzła małżeńskiego nie jest pozbawiony prawa wypowiedzi w tej kwestii. Przeciwstawność jego pozycji w stosunku do małżonków pragnących uzyskać orzeczenie nieważności małżeństwa wyraża się zaś przede wszystkim w możliwości złożenia prośby o zmianę określonej formuły wątpliwości (kan. $1514 \mathrm{KPK} / 83$ ) poprzez usunięcie któregoś z proponowanych tytułów nieważności małżeństwa. Jest to utrudnianie aktywności stron i zajęcie wyraźnie przeciwnego stanowiska $\mathrm{w}$ stosunku do wskazanego przez strony tytułu, który to obrońca węzła uważa za niemożliwy do udowodnienia [Greszata 2008, 26061]. Po ostatecznym określeniu formuły wątpliwości procesowej następuje etap instrukcji sprawy. W małżeńskim procesie skróconym odbywa się posiedzenie dowodowe, w którym powinni wziąć udział strony procesowe, obrońca węzła małżeńskiego i zgłoszeni w sprawie świadkowie (kan. 1685 MIDI). Dla pełnego zagwarantowania realizacji zasady kontradyktoryjności strony procesowe, a także obrońca węzła małżeńskiego mogą zgłaszać środki dowodowe, które uznają za najbardziej odpowiednie do udowodnienia ich twierdzeń (kan. 1526-1527 KPK/83), jak również mają prawo do bycia poinformowanym o dowodach przedstawionych przez pozostałe strony oraz posiadają uprawnienie do zakwestionowania takich dowodów [Lojacono 2014, 20].

W kontekście kontradyktoryjności istotną kwestią wydaje się być niestawiennictwo $\mathrm{w}$ procesie jednej ze stron, pomimo prawidłowego jej wezwania (kan. 1592-1595 KPK/83). Nieobecność strony może wynikać albo z jej własnej woli albo z niezależnych od niej okoliczności. Jeżeli niestawiennictwo jest nieusprawiedliwione, poddawać to może w wątpliwość zadeklarowaną w skardze powodowej chęć prowadzenia procesu o stwierdzenie nieważności małżeństwa. Koniecznym wydaje się wówczas ustalenie, czy strona w ogóle ma zamiar uczestniczyć w procesie. Obecność 
strony powodowej jest bowiem warunkiem koniecznym prowadzenia każdego procesu. W odniesieniu do strony pozwanej, od decyzji instruktora zależy ponowne wezwanie na inny termin sesji lub odbycie posiedzenia bez jej udziału. W przypadku kiedy strona nie stawiła się w wyznaczonym miejscu i terminie na posiedzenie dowodowe ze względu na usprawiedliwioną przyczynę, słusznym rozwiązaniem jest przeprowadzenie kolejnej sesji dowodowej już z udziałem nieobecnego wcześniej małżonka [Majer 2015, 181-82; Góralski 2017, 132-33]. Ze względu na kontradyktoryjność procesu oraz konieczność zachowania prawa do obrony, strona która nie brała udziału w sesji dowodowej ma prawo, szczególnie w perspektywie przygotowania pisma obrończego, do zapoznania się ze zgromadzonym w aktach sprawy materiałem dowodowym [Bianchi 2016, 84-85]. W sposób szczególny zasada kontradyktoryjności uwidacznia się jednakże w następującym po instrukcji sprawy etapie dyskusji sprawy (kan. 1686 MIDI), w którym to, co do zasady, ma miejsce ostateczna wymiana argumentów pomiędzy występującymi w procesie stronami [Sztychmiler 2009, 801802]. W fazie wyrokowania oraz ewentualnego podważania wyroku uprawnienia stron procesowych oraz obrońcy węzła małżeńskiego są takie same [Greszata 2003, 254-55].

Należy zauważyć, iż w procesach małżeńskich w skardze powodowej nie jest przedstawiane roszczenie adresowane do strony pozwanej, ale skierowane do sędziego $\mathrm{w}$ formie prośby o stwierdzenie, że dane małżeństwo zostało zawarte nieważnie (kan. $1502 \mathrm{KPK} / 83$ ). Strona pozwana jest natomiast wzywana do wzięcia udziału w procesie ze względu na fakt, że przedmiot postępowania dotyczy jej praw. Zasada kontradyktoryjności nie wymaga jednak konieczności podjęcia jakichkolwiek działań przez stronę pozwaną. Musi ona jedynie mieć możliwość skorzystania z przysługujących jej uprawnień, o czym należy ją poinformować [Bider i Erlebach 2011, 195]. Małżeński proces skrócony przed biskupem zakłada zaś zgodność stanowisk małżonków, z których to jeden będzie w procesie stroną powodową, a drugi stroną pozwaną. Klasyczny obraz zasady kontradyktoryjności, w którym to strony procesowe przedstawiają sprzeczne ze sobą tezy nie będzie tutaj zrealizowany. Kontradyktoryjność przejawiać się jednakże będzie w przeciwstawności stanowisk stron procesowych i obrońcy węzła małżeńskiego. Warto przy tym zauważyć, że w procesie skróconym zasada kontradyktoryjności może być realizowana w sposób pełny, gdyż przytaczać argumenty na poparcie swoich twierdzeń, z jednej strony będzie 
zawsze oboje małżonków lub przynajmniej jeden z nich w przypadku nieobecności w procesie drugiego (nieobecny może być ten z małżonków, który formalnie wskazany jest jako strona pozwana, gdyż nieobecność strony powodowej uniemożliwia prowadzenie procesu), z drugiej zaś obrońca węzła małżeńskiego, którego udział w procesie o stwierdzenie nieważności jest obowiązkowy (kan. $1433 \mathrm{KPK} / 83$ ).

\section{PODSUMOWANIE}

Zasada kontradyktoryjności jest fundamentalną zasadą procesową. Opiera się na niej struktura każdego procesu spornego, także procesu o nieważność małżeństwa prowadzonego w nowej formie trybu skróconego przed biskupem. Można zgodzić się ze stwierdzeniem, że zasada ta „polega na takiej predyspozycji instrumentów procesowych ze strony prawodawcy i ich aplikacji w dynamice procesu ze strony sędziego, by strony mogły dochodzić i bronić swoich praw na forum sądowym w ramach słusznego procesu" [Bider i Erlebach 2011, 193].

Należy podkreślić, iż realizacja zasady kontradyktoryjności w małżeńskim procesie skróconym, poprzez aktywność stron procesowych i obrońcy węzła przede wszystkim umożliwia orzekającemu w sprawie biskupowi diecezjalnemu dokładne zapoznanie się z okolicznościami dotyczącymi zaskarżanego małżeństwa i w konsekwencji podjęcie decyzji w postaci wyroku stwierdzającego nieważność małżeństwa lub przekazania sprawy do rozpatrzenia w trybie procesu zwykłego (kan. $1687 \S 1$ MIDI).

\section{PIŚMIENNICTWO}

Adamowicz, Leszek. 2015. „Okoliczności osób i rzeczy zezwalające na prowadzenie procesu skróconego.” W Proces matżeński według motu proprio Mitis Iudex Dominus Iesus, red. Jan Krajczyński, 93-108. Płock: Płocki Instytut Wydawniczy.

Ariano, Chiara. 2017. „Il principio del contraddittorio. Lineamenti comparativi tra processo italiano e canonico." Prudentia Iuris 84:165-89.

Arroba Conde, Manuel J. 2016. Giusto processo e peculiarita culturali del processo canonico. Roma: Aracne Editrice.

Arroba Conde, Manuel J., i Claudia Izzi. 2017. Pastorale giudiziaria e prassi procesuale nelle cause di nullità del matrimonio. Dopo la riforma operata con il Motu proprio Mitis Iudex Dominus Iesus. Milano: San Paolo. 
Bianchi, Paolo. 2016. „Lo svolgimento del processo breve: la fase istruttoria e di discussione della causa." W La riforma dei processi matrimoniali di Papa Francesco. Una guida per tutti, red. Redazione di Quaderni di Diritto Ecclesiale, 67-90. Milano: Ancora Editrice.

Bider, Marcin, i Grzegorz Erlebach. 2011. „Kwestia momentu procesowego uznania pozwanego nieobecnym w procesie o nieważność małżeństwa.” Roczniki Nauk Prawnych 21, nr 1:181-206.

Bonnet, Piero A. 2018. „Le parti protagoniste del processo.” W I soggetti del nuovo processo matrimoniale canonico, 69-102. Cittá del Vaticano: Libreria Editrice Vaticana.

Daniel, William. 2015. „The Abbreviated Matrimonial Process before the Bishop in Cases of Manifest Nullity of Marriage." The Jurist 75:539-91.

Del Amo, Leon. 2011. „Dowody.” W Codex Iuris Canonici. Kodeks Prawa Kanonicznego. Komentarz. Powszechne i partykularne ustawodawstwo Kościoła katolickiego. Podstawowe akty polskiego prawa wyznaniowego. Edycja polska na podstawie wydania hiszpańskiego, red. Piotr Majer, 1147-190. Kraków: Wolters Kluwer Polska.

Del Pozzo, Massimo. 2016. Il processo matrimoniale più breve davanti al Vescovo. Roma: Edizioni Università della Santa Croce.

Dotti, Federica. 2005. Diritti della difesa e contraddittorio: garanzia di un giusto processo? Spunti per una riflessione comparata del processo canonico e statale. Roma: Gregorian and Biblical Press.

Dzierżon, Ginter. 2015. „Pewność moralna w procesie skróconym i w procesie zwyczajnym." W Proces matżeński według motu proprio Mitis Iudex Dominus Iesus, red. Jan Krajczyński, 109-24. Płock: Płocki Instytut Wydawniczy.

Gałkowski, Tomasz. 2016. „Papieska Rada ds. Tekstów Prawnych wobec wątpliwości związanych z Listem apostolskim Mitis Iudex Dominus Iesus.” Ius Matrimoniale 27, nr 2:21-54.

Góralski, Wojciech. 2017. Proces matżeński skrócony przed biskupem. Płock: Płocki Instytut Wydawniczy.

Greszata, Marta. 2003. „Problem kontradyktoryjności w kanonicznym postępowaniu o nieważność małżeństwa.” W Kościelne Prawo Procesowe. Materiały $i$ studia, t. 3, red. Andrzej Dzięga, i Mirosław Wróbel, 239-58. Lublin: Wydawnictwo Diecezjalne w Sandomierzu.

Greszata, Marta. 2005. „Litispendencja i jej skutki w kanonicznym procesie o nieważność małżeństwa." Roczniki Nauk prawnych 15, nr 2:249-62.

Greszata, Marta. 2008. Iudicium cum principiis. Kodeksowa weryfikacja wybranych zasad procesowych $w$ kanonicznych sprawach o nieważność matżeństwa. Lublin: Wydawnictwo Diecezjalne i Drukarnia w Sandomierzu.

Greszata-Telusiewicz, Marta. 2015. „Processus brevior.” W Proces małżeński wedtug motu proprio Mitis Iudex Dominus Iesus, red. Jan Krajczyński, 75-92. Płock: Płocki Instytut Wydawniczy.

Krukowski, Józef. 2007. „Sądy w ogólności.” W Komentarz do Kodeksu Prawa Kanonicznego. T. V: Księga VII Procesy, red. Józef Krukowski, 12-122. Poznań: Pallottinum.

Lojacono, Pietro. 2014. „Il diritto di difesa nel processo canonico: considerazioni introduttive e spunti ricostruttivi." Rivista dell 'Associazione Italiana degli Avvocati per la famiglia e per i minori 18, nr 1:15-28.

Majer, Piotr. 2015. „Art. 5/Tytuł V Proces małżeński skrócony przed biskupem.” W Praktyczny komentarz do Listu apostolskiego motu proprio Mitis Iudex Dominus 
Iesus papieża Franciszka, red. Piotr Skonieczny, 163-217. Tarnów: Wydawnictwo Diecezji Tarnowskiej Biblos.

Montini, Gian P. 2017. „Il difensore del vincolo e l'obbligo dell'appello.” Periodica de Re Canonica 106:301-39.

Morán Bustos, Carlos M. 2016. „El proceso brevior ante el obispo diocesano.” W Procesos de nulidad matrimonial tras la reforma del Papa Francisco, red. María Olmos Ortega, Rafael Rodríguez Chacón, Manuel J. Arroba Conde, i in., 125-76. Madrid: Dykinson.

Moreno, Pedro. 2017. „Il DV è il garante di un vero contraddittorio per il discernimento della verità." W Ius et Matrimonium II. Temi processuali e sostanziali alla luce del Motu Proprio Mitis Iudex Dominus Iesus, red. Héctor Franceschi, i Miguel Ortiz, 179-218. Roma: Edizioni Università della Santa Croce.

Napolitano, Erasmo. 2015. „Il processus brevior nella Lettera Apostolica motu proprio datae Mitis Iudex Dominus Iesus." Monitor Ecclesiasticus 130, nr 2:549-66.

Nowicka, Urszula. 2015. „Okoliczności dopuszczające rozpoznanie sprawy o nieważność małżeństwa w procesie skróconym przed biskupem.” Ius Matrimoniale 26, nr 3:43-60.

Pawlak, Mikołaj. 2007. „Zadanie asesora w trybunale kościelnym.” W Kościelne Prawo Procesowe. Materiały i studia, t. 4, red. Andrzej Dzięga, Marta Greszata, i Piotr Telusiewicz, 345-68. Lublin: Wydawnictwo Diecezjalne w Sandomierzu.

Pawluk, Tadeusz. 1990. Prawo Kanoniczne wedtug Kodeksu Jana Pawła II. T. 4: Dobra doczesne Kościoła. Sankcje w Kościele. Procesy. Olsztyn: Warmińskie Wydawnictwo Diecezjalne.

Pikus, Szymon. 2009. Niezawistość sędziego kościelnego. Lublin-Sandomierz: Wydawnictwo Diecezjalne w Sandomierzu.

Román Sánchez, Raúl. 2018. „Juez único, jueces laicos y asesores en el motu proprio Mitis Iudex Dominus Iesus.” Revista Española de Derecho Canónico 75:235-72.

Rozkrut, Tomasz. 2018a. „Apelacja ze strony obrońcy węzła małżeńskiego we współczesnym zreformowanym procesie małżeńskim." Annales Canonici 14, nr 2:271-90.

Rozkrut, Tomasz. 2018b. „Terminy procesowe w kontekście reformy kanonów dotyczących spraw o orzeczenie nieważności małżeństwa dokonanej przez papieża Franciszka." Annales Canonici 14, nr 1:51-68.

Rozkrut, Tomasz. 2018c. „Wybrane oraz praktyczne uwagi odnoszące się do zreformowanego przez papieża Franciszka procesu dotyczącego orzeczenia nieważności małżeństwa (w szczególności w przedmiocie procesu biskupiego).” W Reforma procesowa papieża Franciszka - pierwsze doświadczenie. Materiały z ogólnopolskiego spotkania pracowników sqdownictwa kościelnego w Gródku nad Dunajcem w dniach 1213 czerwca 2017 roku, red. Tomasz Rozkrut, 179-92. Tarnów: Wydawnictwo Diecezji Tarnowskiej Biblos.

Sztychmiler, Ryszard. 2000. „Sędziowie i urzędnicy sądowi w służbie praw człowieka.” W Plenitudo Legis Dilectio. Ksiega pamiatkowa dedykowana prof. dr. hab. Bronistawowi W. Zubertowi OFM z okazji 65. rocznicy urodzin, red. Antoni Dębiński, i Elżbieta Szczot, 681-707. Lublin: Redakcja Wydawnictw KUL.

Sztychmiler, Ryszard. 2009. „Prawo do obrony w procesie kanonicznym.” W Finis legis Christus. Księga pamiatkowa dedykowana Księdzu Profesorowi Wojciechowi Góralskiemu z okazji siedemdziesiatej rocznicy urodzin, red. Józef Wroceński, i Jan Krajczyński, 791-807. Warszawa: Wydawnictwo UKSW. 
Wenz, Wiesław. 2016. Proces o nieważność małżeństwa wedtug Motu Proprio Mitis Iudex Dominus Iesus Papieża Franciszka w tradycji kanonicznej. Wrocław: Papieski Wydział Teologiczny.

Witkowski, Wojciech. 2014. „Kryteria oceny dowodów w procesach o nieważność małżeństwa.” Kościół i Prawo 3 (16), nr 1:87-107.

Zuanazzi, Ilaria. 1994. „Le parti e l'intervento del terzo.” W Il processo matrimoniale canonico, red. Piero A. Bonnet, i Carlo Gullo, 323-91. Città del Vaticano: Libreria Editrice Vaticana.

\section{Zasada kontradyktoryjności w małżeńskim procesie skróconym przed biskupem}

\section{Streszczenie}

Małżeński proces skrócony przed biskupem jest nową formą procesu o stwierdzenie nieważności małżeństwa. Prowadzony może być w sytuacji, kiedy żądanie jego rozpoczęcia zgłoszone zostanie przez obydwoje małżonków lub przez jednego $\mathrm{z}$ nich za zgodą drugiego oraz przytoczone będą okoliczności dotyczące faktów lub osób poparte zeznaniami lub dokumentami, które nie wymagają przeprowadzenia dokładniejszego badania albo dochodzenia, a w sposób oczywisty wskazują na nieważność zaskarżanego małżeństwa. Należy jednak podkreślić, że dojście do prawdy o ważności zawartego małżeństwa możliwe jest tylko przy zachowywaniu od samego początku regulujących takie postępowanie sądowe norm prawnych oraz zasad procesowych.

Jedną z podstawowych zasad jest zaś zasada kontradyktoryjności. Odnosi się ona do stron procesowych i zakłada istnienie dwóch sprzecznych ze sobą tez. W kontekście procesu skróconego ma zaś miejsce przeciwstawność tego, co twierdzą strony na temat nieważności zawartego przez nie związku i tego, na jakim stanowisku stoi Kościół, broniąc ważności małżeństwa w osobie obrońcy węzła małżeńskiego występującego w procesie.

Słowa kluczowe: strony procesowe; obrońca węzła małżeńskiego; nieważność małżeństwa; spór

\section{The Contradictory Principle in the Briefer Matrimonial Process Before the Bishop}

\section{Summary}

The briefer matrimonial process before the bishop is a new form of the nullity marriage. The process is carried out whenever the petition is proposed by both spouses or by one of them, with the consent of the other or circumstance of things and persons recur, with substantiating testimonies and records, which do not demand a more accurate inquiry or investigation, and which render the nullity manifest. However, the truth about the validity of marriage can only be obtained if the legal norms and the way of proceeding are observed. 
One of the basic principles is contradictoriness. It refers to the parties and assumes the existence of two contradictory theses. In the context of the briefer process, there is a contradiction between what the parties claim about the nullity of their marriage and the position of the Church defending the validity of marriage through the defender of the bond occurring in the process.

Key words: parties; defender of the bond; nullity of marriage; litigation

Information about Author: Aleksandra ŁukAsiK, J.C.L., Ph.D. STUdent - Department of Church Procedural Law, Marriage and Criminal Law and Eastern Catholic Churches, Institute of Canon Law, Faculty of Law, Canon Law and Administration, the John Paul II Catholic University of Lublin; e-mail: aleksandra. rybaczek@wp.pl; https://orcid.org/0000-0002-2880-1307 